\title{
A Case Study regarding Capstone Design Classes on Community Oral Health
}

\author{
Sun-Ju Kim1)
}

\begin{abstract}
This paper presents a case study regarding a community oral health Capstone Design class, which was conducted based on community cooperation. The Community Oral Health Capstone Design was established in the second semester of 2019 and conducted over a period of 15 weeks using two teams of 10 students. The overall class structure was divided into an introduction stage, execution stage, and evaluation stage. Compared to traditional lecture-based classes, this approach offers many advantages and generates positive results for learners, professors, and the community. This process also has the educational effects of resolving inconsistencies with team members, coordinating one's own opinions, reconciling individual opinions with those of other team members, and deriving optimal results, while providing communities with the opportunity to work with schools to solve problems in their organizations. In the future, continuous research on the educational effects of students in Capstone classes should be conducted, and further discussion will be necessary in order to develop a curriculum that can apply Capstone Design programs to the dental hygiene curriculum.
\end{abstract}

Keywords: Capstone, Design, Dental, Hygiene, Community, Oral, Health

\section{Introduction}

Capstone Design is a school-industry cooperative program designed to foster professional expertise by enabling learners to create and manufacture products, based on their majors, that can be used on-site in the industry. It thus helps develop both their practical skills and teamwork[1]. Unlike traditional lectures, Capstone Design classes refer to a comprehensive process that concludes what a student has learned at university, incorporating knowledge learned from the curriculum with the delivery of results[2]. Since being introduced and applied in domestic universities, Capstone Design classes have continuously evolved and expanded into various academic fields, breaking away from the general comprehensive system of experiential education. Along with requiring students to think creatively, they also provide a comprehensive system of education through the cooperation of schools and industries[3]. A number of recent

Received(September 26, 2019), Review Result(1st: October 22, 2019, 2nd: November 30, 2019), Accepted(January 30, 2020)

1) (Professor) 28503 Dept. Dental hygiene, College of Health \& Medical Sciences, Cheongju Univ., Daesung-ro 298, Cheongwon-gu, Cheongju-si, South Korea

email: sjkim@cju.ac.kr 
studies have demonstrated that Capstone Design classes are effective in improving students' creative problem-solving abilities, triggering an increased interest in this approach, while also boosting academic achievement and improving academic satisfaction[1][3-6]. As a result, many universities are now introducing Capstone Design classes that, unlike traditional classes, allow students to solve problems, conduct research, and develop their careers by integrating the knowledge they have acquired during their undergraduate studies. In Capstone Design, communities and industries work together and form relationships with individual schools, partaking in actual problem-solving processes. It is a program that fosters professional experts in line with local demand[7]. While programs that incorporate either Capstone Design approaches or other creative systems are held relatively frequently in the engineering field, such creative-convergent programs have not been developed and operated in the health, humanities, or social fields. A student majoring in dental hygiene should be prepared to acquire the necessary knowledge, skills, attitude, and values required to respond appropriately to the variety of clinical situations and potential problems they will face in becoming dental professionals[8]. If they experience the process of planning, performing, and analyzing tasks related to community oral health, developing competence as oral health educators through a comprehensive design, they will be able to undergo their education more effectively than they could through existing, lecture-based approaches. Therefore, the purpose of this study is to introduce programs that use Capstone Design in the field of community oral health. This study proposes a Capstone Design model that can be applied in the field of dental hygiene by systemizing the activities, output factors, and implications of the operation process.

\section{Introduction to Capstone Design}

\subsection{Definition and Operational Processes of Capstone Design}

In architecture, a Capstone refers to the stone that is placed on top of a wall or building as either an embellishment or a finishing touch[4]. The definition of Capstone Design varies from scholar to scholar, but it is generally considered to represent a comprehensive system of education that incorporates planning, design, and manufacturing in order to foster the ability to solve the real-life problems. Students, professors, and field experts collaborate in creative workforce training to foster the talent of students, helping them to become accustomed to the field by developing skills that the industry in question requires[3][9][10].

Capstone Design classes aim to perform creative workforce training designed to foster 
individuals who are capable of adapting to the industrial field. This holistic program, in which the student, professor, and industry plan, design, produce, and present projects together, offers various advantages, such as fostering creativity, efficiency, stability, economic understanding, teamwork, problem-solving techniques, and communication [Fig. 1].

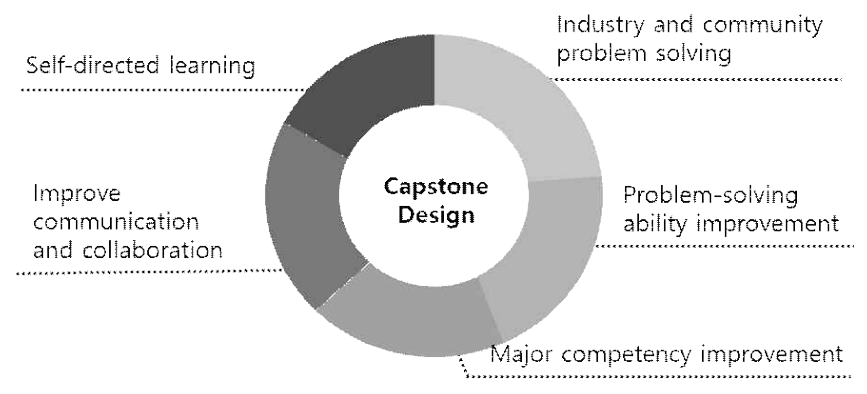

[Fig. 1] The Effects of the Capstone Design Curriculum

It is introduced as an educational method through which you can foster creative manpower in ways that meet industry demands[11]. Types of Capstone Design can be executed in various ways, depending on factors such as operation method and theme setting. Seo[12] classified Capstone Design into different types: creative, multidisciplinary, industry-linked, community-linked, and global [Table 1]. The creative type mainly involves students performing assignments in order to first produce designs and then manufacture them. The multidisciplinary type is convergent and comprehensive; students from different majors form teams to solve problems and produce prototypes. The industry-linked type is operated through the process of identifying and solving the existing problems within the given industry, which provides feedback and acts as a mentor.

In the community-linked type, public institutions, local governments, industries, and universities establish a cooperative system through which they solve problems. In the global type, the school cooperates with foreign universities and businesses to form teams with students in order to produce, design, and perform tasks. The purpose of this study is to present a case study regarding an oral health Capstone Design class based on community cooperation.

[Table 1] Main Types of Capstone Design

\begin{tabular}{|c|c|}
\hline \multicolumn{1}{|c|}{ Types } & \multicolumn{1}{|c|}{ Contents } \\
\hline Creative type & Mainly involves students who perform assignments, produce designs, and \\
\hline
\end{tabular}




\begin{tabular}{|l|l|}
\hline Multidisciplinary type & $\begin{array}{l}\text { A convergent and comprehensive process in which students from different } \\
\text { majors form teams to solve problems and produce prototypes }\end{array}$ \\
\hline Industry-linked type & $\begin{array}{l}\text { A process that identifies and solves problems in the industry, which provides } \\
\text { feedback and acts as a mentor }\end{array}$ \\
\hline $\begin{array}{l}\text { Community-linked } \\
\text { type }\end{array}$ & $\begin{array}{l}\text { Public institutions, local governments, industries, and universities establish a } \\
\text { cooperative system through which they solve problems }\end{array}$ \\
\hline Global type & $\begin{array}{l}\text { Schools cooperate with foreign universities and businesses to form teams with } \\
\text { students in order to produce, design, and perform tasks }\end{array}$ \\
\hline
\end{tabular}

\subsection{Capstone Design in the Field of Oral Health}

Dental hygienists are professional health workers who are responsible for the promotion of citizens' oral health by supporting related education, preventive dentistry, dental-medical cooperation, and business management for both local residents and people with dental problems. Dental hygiene education should prepare students with the necessary knowledge, skills, attitude, and values to respond appropriately to the various clinical situations they might face as dental professionals. A Capstone Design approach applied to dental hygiene allows students to experience the processes of planning, performing, and analyzing tasks related to community oral health activities. Such an education can be performed more effectively than the existing forms of instruction. As a result of social demands and the direction of government policies, many universities have mandated the introduction of Capstone Design courses, extending their application to the domains of health, humanities, and social sciences. Thus, Capstone Design is being applied increasingly in the field of dental hygiene.

\section{Designing the Capstone Design's Curriculum and Operation}

\subsection{Designing the Capstone Design curriculum}

This study is based on the curriculum of the Community Oral Health and Oral Health Education departments, as well as the subject "Community Oral Health Capstone Design."

The Community Oral Health Capstone Design Class has a curriculum that aims to cultivate creative talent by helping students experience the process of planning, performing, and analyzing oral health education tasks for participants from the community, thereby developing their planning, collaborative, and practical skills.

The comprehensive design of the oral health education program for lifecycle oral health management and promotion, which is directed at each local community, helps to boost the 


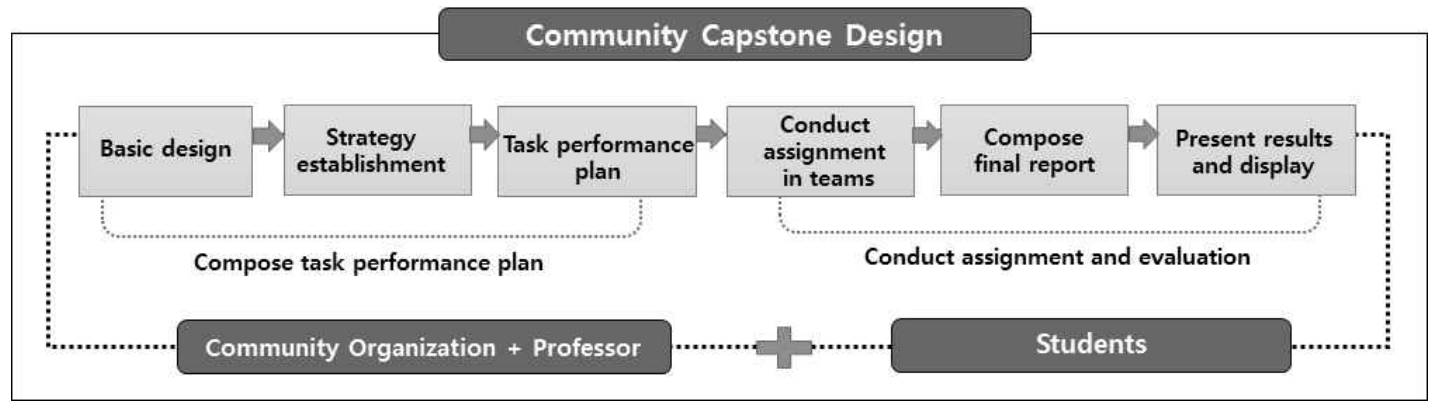

[Fig. 2] Development Process of Capstone Design Classes

\subsection{Capstone Design Curriculum Operational Processes}

The Community Oral Health Capstone Design was established in the second semester of 2019 and was then conducted over a period of 15 weeks using two teams of 10 students. Each team was given a stipend of 300,000 Won. The overall class structure was divided into an introduction stage, execution stage, and evaluation stage, as shown in Table 2.

\subsubsection{Course Introduction and Team Composition}

We introduced the concept of Capstone Design in the first week in order to ensure that the students had sufficient time to understand the curriculum. A Q\&A was also held to facilitate this process. In addition, as Capstone Design classes should be conducted in conjunction with the community (industry), we also designated an organization and introduced it to the students. For the participating community organizations per lifecycle, we chose to conduct our project on early childhood oral health education. For this purpose, the professor selected four community daycare centers where we could conduct oral health education before the semester started.

\subsubsection{Dividing Team Roles and Choosing a Theme}

Lectures were conducted as team projects. Teams were composed of the professor and students, and team composition was organized autonomously based on students' interests. The teams were then asked to discuss and select project topics based on the demands of the community, and, after a theme was chosen, each teammate took on a specific role within the team. The task that the community organization requested was related to the creation and instruction of 
infant oral health education media. We executed a project in which one of the teams was responsible for producing and distributing educational media, while the other was responsible for producing and teaching oral health education textbooks [Table 2].

[Table 2] Syllabus for the Community Oral Health Capstone Design

\begin{tabular}{|c|c|c|c|}
\hline \multicolumn{2}{|c|}{ Course Title } & \multicolumn{2}{|l|}{ Capstone Design: Community Oral Health } \\
\hline \multicolumn{2}{|c|}{ Course Goals } & \multicolumn{2}{|c|}{$\begin{array}{l}\text { This course aims to cultivate creative manpower capable of planning, working } \\
\text { in teams, and developing practical skills by allowing students to plan, } \\
\text { perform, and analyze tasks related to oral health education. It aims to develop } \\
\text { the capacity of oral health educators through a comprehensive design of } \\
\text { community programs for oral health management and promotion. }\end{array}$} \\
\hline \multicolumn{2}{|c|}{ Course Evaluation } & \multicolumn{2}{|c|}{$\begin{array}{l}20 \% \text { attendance and participation, } 20 \% \text { operation plan, } 20 \% \text { final report and } \\
\text { achievement, } 20 \% \text { community assessment, and } 20 \% \text { presentation and exhibition }\end{array}$} \\
\hline \multicolumn{2}{|c|}{ Course Plan } & Course Description & Main Objectives \\
\hline \multirow{2}{*}{$\begin{array}{l}\text { Introduction } \\
\text { Stage }\end{array}$} & Week 1 & $\begin{array}{l}\text { Introduction to Capstone Design Curriculum } \\
\text { - Explanation of the aims of the curriculum and an } \\
\text { analysis of the curriculum } \\
\text { - Forming teams and researching topics in teams }\end{array}$ & $\begin{array}{l}\text { - Introducing curriculum } \\
\text { - Forming teams and } \\
\text { researching topics }\end{array}$ \\
\hline & Week 2 & $\begin{array}{l}\text { Review community needs to create task performance } \\
\text { plan } \\
\text { - Debate and give presentations on assigned topics } \\
\text { - Designate roles within teams } \\
\text { - Compose a draft of the task performance plan }\end{array}$ & $\begin{array}{l}\text { - Review community needs } \\
\text { - Task performance plan }\end{array}$ \\
\hline \multirow[t]{2}{*}{ Initial Stage } & Week 3 & $\begin{array}{l}\text { Visit and interview community organization } \\
\text { - Interview with a community organization } \\
\text { representative } \\
\text { - Identify the requirements for performance } \\
\text { - Check the status of community organization and } \\
\text { educational environment }\end{array}$ & $\begin{array}{l}\text { - Visit and interview } \\
\text { community organization }\end{array}$ \\
\hline & Week 4 & $\begin{array}{l}\text { Draw up a community plan for each team } \\
\text { - Prepare a task plan for each community organization } \\
\text { - Finalize agreements with community organizations }\end{array}$ & $\begin{array}{l}\text { - Sign a project agreement } \\
\text { and appoint a community } \\
\text { advisor }\end{array}$ \\
\hline \multirow[t]{2}{*}{$\begin{array}{l}\text { Progress } \\
\text { Stage }\end{array}$} & $\begin{array}{l}\text { Week } \\
5-8\end{array}$ & $\begin{array}{l}\text { Stage 1: Conduct assignments in teams } \\
\text { - Presentation of task performance by community } \\
\text { organization } \\
\text { - Presentation of the medium for carrying out } \\
\text { assignments from community organizations } \\
\text { Stage 2: Conduct assignments in teams and interim } \\
\text { check } \\
\text { - Check the progress of oral health education media } \\
\text { production } \\
\text { - Presentation of community health and health } \\
\text { education textbooks and content }\end{array}$ & $\begin{array}{l}\text { - Activities in teams } \\
\text { - Instruction and evaluation } \\
\text { by professor (Interim check } \\
\text { and instruction) }\end{array}$ \\
\hline & $\begin{array}{l}\text { Week } \\
9-13\end{array}$ & $\begin{array}{l}\text { Stage 3: Work on the assignment in teams } \\
\text { - Check the educational media and conduct education } \\
\text { - Discuss the results of media utilization and the } \\
\text { performance of education } \\
\text { - Analyze the advantages and disadvantages of the }\end{array}$ & $\begin{array}{l}\text { - Activities in teams } \\
\text { - Instruction and evaluation } \\
\text { by professor }\end{array}$ \\
\hline
\end{tabular}




\begin{tabular}{|c|c|c|c|}
\hline & & $\begin{array}{l}\text { performance of education } \\
\text { - Discuss room for improvement }\end{array}$ & (n) \\
\hline \multirow{2}{*}{$\begin{array}{l}\text { Evaluation } \\
\text { Stage }\end{array}$} & Week 14 & $\begin{array}{l}\text { Compose the final report } \\
\text { - Turn in the final report } \\
\text { - Presentation and competition } \\
\text { - Evaluation by the professor and community } \\
\text { organization }\end{array}$ & $\begin{array}{l}\text { - Instruction and evaluation } \\
\text { by community organization } \\
\text { - Instruction and evaluation } \\
\text { by professor }\end{array}$ \\
\hline & Week 15 & $\begin{array}{l}\text { Summarize the content for the semester and choose } \\
\text { the best team } \\
\text { - Designate the best team and conduct the award } \\
\text { ceremony } \\
\text { - Present and display the results }\end{array}$ & - Comprehensive evaluation \\
\hline
\end{tabular}

\subsubsection{Preparation and Presentation of the Project Performance Plan}

During weeks 3-4, we reviewed the assignment performance plans regarding the selected topics face-to-face with students and the community organizations, exploring and discussing various requirements and issues. During this process, the agencies explained to students the current status of and problems associated with the task and provided a range of information for writing the task performance plans. In addition, community childcare and oral health specialists were appointed as advisors in order to help students understand the community assignment tasks, build materials, and develop basic plans for future projects. Each team announced a project implementation plan and coordinated a specific schedule for progress. The task performance plan provided background information regarding task selection, the necessity of the task, and the task's objectives and main content, as well as the strategy of the project, its expected outcomes and effects, utilization plans, and budget [Fig. 3].
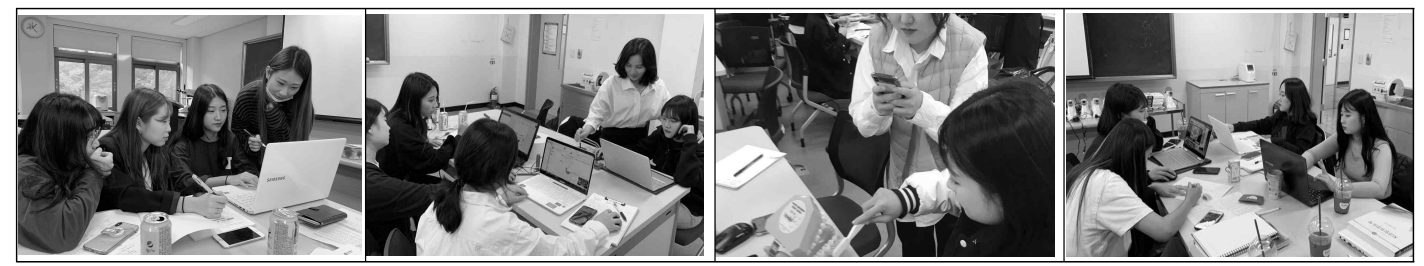

[Fig. 3] Preparation and Presentation of the Project Performance Plan

\subsubsection{Task Performance}

Team assignments were carried out according to the lesson plan for each week. During weeks 5-13, tasks were carried out in teams, based on the completed task plan; each week, students were given time to present and check their task performance. Since the oral health education 
activities were to be held on-site in the local community, they were conducted during designated out-of-lecture hours. A team meeting was also held each week, and the professor set separate interview times to receive weekly progress reports from each team.

Each team conducted their assignments under the guidance of their advisors over a period of nine weeks, while also providing an interim report presentation. During this presentation, they went over their progress, content, results, and other relevant information related to the tasks that the industry requested and also discussed how they would improve their undertaking of the assignment in the future. In weeks 12-13, we delivered the media produced through the curriculum to the community daycare centers and conducted oral health education for infants [Fig. 4].

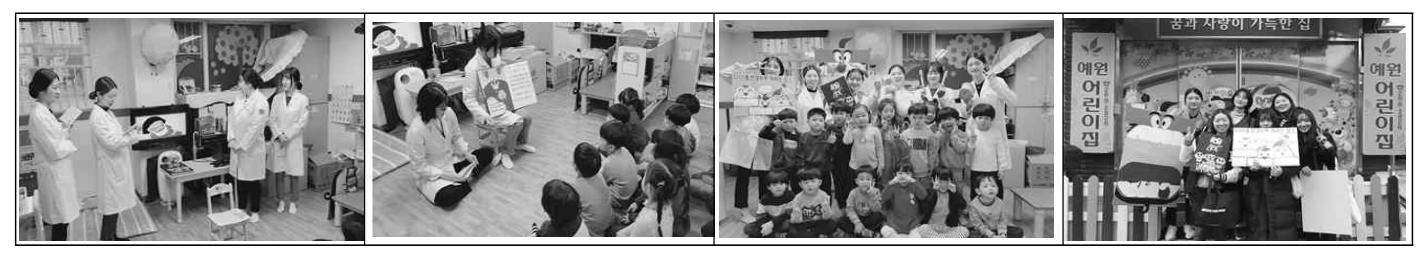

[Fig. 4] Operation of the Capstone Design (Community Education Activities)

\subsubsection{Final Outcome Presentation and Class Evaluation}

The final report presentation was attended by the professor, community advisors, and students. The final results and achievements were presented, while students received also feedback from the participants. During this process, various problems were presented, as well as ideas that each team had not thought of. These were to be included in the final report [Fig 5].
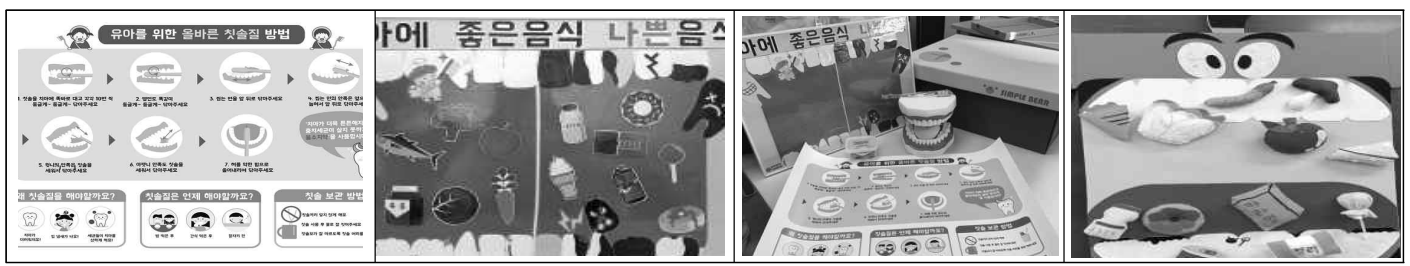

[Fig. 5] Final Results of the Capstone Design Class (Oral Health Educational Media)

\section{Conclusion}

Dental hygiene education consists of practical skills, creative planning, problem-solving, and communication, all of which represent essential skills students pursuing careers in dental 
hygiene require, to be able to face the various clinical situations and problems that may arise. The current dental hygiene curriculum is overly subdivided to prepare students for the national examination and is dominated by theory-based lectures on professional medical knowledge. Therefore, there are limited opportunities for students to develop their individual role and function[13].

This study presents the development and operation of a community oral health Capstone Design class. Compared to traditional lecture-based classes, this approach offers many advantages and generates positive results for learners, professors, and the community. In Capstone Design, students work as part of a team, investigating necessary data, outlining ideas, and communicating in an effective manner, with the aim of making optimal decisions and fulfilling one's role in the group[2]. This process has the educational effects of resolving inconsistencies with team members, coordinating an individual's opinions, reconciling individual opinions with those of other team members, and deriving optimum results. Furthermore, this approach also offers communities the opportunity to work with schools to solve problems in their organizations. The wider application of Capstone Design to the dental hygiene curriculum will enhance students' skills in problem-solving, communication and practical application as oral health educators, while also expanding their capacities within the major to improve learning outcomes.

Only a few schools currently apply a Capstone Design approach to classes in the field of dental hygiene, and very few studies proving the effectiveness of these classes in this field have been conducted. In the future, continuous research on the educational effects of students in Capstone classes will be needed, while further discussion will also be necessary in order to develop a curriculum that can apply Capstone Design to the dental hygiene curriculum.

\section{References}

[1] E. H. Kim, Y. G. Ko, and S. N. Kim, Effects of a capstone nursing research course for nursing students, The Journal of Learner-Centered Curriculum and Instruction, (2016), Vol.16, No.10, pp.473-492, DOI: 10.22251/jlcci.2016.16.10.473

[2] T. S. Lee, Y. J. Jeon, D. W. Lee, B. C. Jang, Present situation and student satisfaction of engineering capstone design course in engineering colleges of Korea, Journal of Engineering Education Research, (2009), Vol.12, No.2, pp.36-50, DOI: 10.18108/jeer.2009.12.2.36

[3] H. G. Kim, Development of Design Product by Utilizing Capstone Design Education - Development of design for industry - academia linked cultural product -, Journal of Digital Design, (2016), Vol.16, No.4, 
pp.124-134, UCI: G704-001614.2016.16.4.023

[4] J. H. Jung, A study on the effect and the development of creative engineering technology education program based on capstone design in elementary, Journal of Korean Practical Arts Education, (2012), Vol.25, No.4, pp.195-215, UCI: G704-000635.2012.25.4.008

[5] Y. H. Noh, A study on the LIS capstone design curriculum and the learning satisfaction survey, Journal of Korean Library and Information Science Society, (2015), Vol.46, No.3, pp.89-118, DOI: 10.16981/kliss.46.3.201509.89

[6] M. H. Yoon, Capstion Design Applications and Performance in the Field of Design, The Journal of Korea Contents Association, (2012), Vol.12, No.12, pp.111-118, DOI: 10.5392/JKCA.2012.12.12.111

[7] H. J. Shin, A study on the application of capstone design method to a community organization education, Asia-pacific Journal of Multimedia Services Convergent with Art, Humanities, and Sociology, (2017), Vol.7, No.11, pp.135-146, DOI: 10.35873/ajmahs.2017.7.11.014

[8] S. J. Kim, The effect on learning satisfaction among dental hygiene students following a capstone design on oral health education, Asia-pacific Journal of Multimedia Services Convergent with Art, Humanities, and Sociology, (2017), Vol.7, No.8, pp.655-667, DOI: 10.35873/ajmahs.2017.7.8.062

[9] I. S. Park and D. K. Kim, A study on dental hygiene students effects of team-based learning in the dental hygiene curriculum on learning motivation and self-directed learning capabilities, Journal of Korean Society of Dental Hygiene, (2010), Vol.10, No.1, pp.127-140, UCI: G704-SER000010586.2010.10.1.004

[10] A. L. Kim, Y. K. Kim, Y. S. Song, K. R. Shin, H. J. Ahn, J. S. Lee, and K. H. Jo, A study for the development of a problem-based learning package for patients with perception-adjustment disorder, Journal of Adult Nursing, (2001), Vol.13, No.3, pp.385-396.

[11] S. H. Han, A fundamental study on development of a capstone design instructional method: based on ISO 10015, Asia-pacific Journal of Multimedia Services Convergent with Art, Humanities, and Sociology, (2016), Vol.6, No.12, pp.133-141, DOI: 10.35873/ajmahs.2016.6.12.012

[12] Y. H. Sur and H. A. Sim, Development and effectiveness analysis of global capstone design program for students majoring in visual design, Journal of Basic Design \& Art, (2016), Vol.17, No.2, pp.184-194, UCI: G704-001069.2016.17.2.009

[13] G. Y. Choi and H. S. Kwon, An Analysis of the Decision-Making Process in the Dept. of Dental Hygiene Curriculum, Journal of Vocational Education \& Training, (2010), Vol.13, No.3, pp.199-220, DOI: 10.36907/krivet.2010.13.3.199 